\title{
MORPHOLOGICAL STUDY OF RED LAKE IN DINARIC KARST BASED ON TERRESTRIAL LASER SCANNING AND SONAR SYSTEMS
}

\author{
MORFOLOŠKA ŠTUDIJA CRVENEGA JEZERA V DINARSKEM \\ KRASU NA PODLAGI TERESTIČNEGA LASERSKEGA \\ SKENIRANJA IN SONARNEGA SISTEMA
}

\author{
Ivo ANDRIĆ' \& Ognjen BONACCI ${ }^{1}$
}

\begin{abstract}
UDC $556.55: 528.8(497.5)$

551.435.8:528.8(497.5)

Ivo Andrić \& Ognjen Bonacci: Morphological study of Red lake in Dinaric karst based on terrestrial laser scaning and sonar system

Red Lake (Dinaric karst, Croatia) is an exceptional karst phenomenon, worldwide known for its beauty and extreme depth. Even so, through the history of Red Lake's research there were many controversies in the conclusions and the theories concerning its genesis, geomorphology and hydrology. The aim of this work is to give an overview of existing findings about Red Lake as well as to present the newest research results gained with the help of emerging technologies based on terrestrial laser scanning and hydro acoustics. The measuring was conducted during September 2013. A new generation of equipment developed to advance the geoscientific research was deployed during the field work. The gathered data enabled a thorough analysis which led to new important findings on Red Lake. Deployment of Remotely operated underwater vehicle (ROV) equipped with imaging sonar resulted in the first hydro acoustic survey of the lake. Some of the results confirmed the already known and well documented characteristics of Red Lake whereas others disputed the widely accepted assumptions in the scientific community and the general public. The presented research generated, for the first time, a DEM for Red Lake which allowed a good estimate on the lake's volume. For the recorded maximum water level at $311 \mathrm{~m}$ a.s.l. the volume of water stored is $8.24 \times 10^{6} \mathrm{~m}^{3}$. A temperature profile of the lake was recorded during the field work and it offered an insight on possible water mixing through karst conduits near the surface of the water. The application of TLS and ROV sonar systems considerably improved the understanding of Red Lake's morphology.
\end{abstract}

Keywords Lidar, Sonar, Red Lake (Croatia), Dinaric karst.
Izvleček

UDK 556.55:528.8(497.5) 551.435.8:528.8(497.5)

Ivo Andrić \& Ognjen Bonacci: Morfološka študija Crvenega jezera $v$ Dinarskem krasu na podlagi terestičnega laserskega skeniranja in sonarnega sistema

Crveno jezero (Dinarski kras, Hrvaška) je izjemen kraški pojav, po vsem svetu poznan po svoji lepoti in skrajnih globinah. Kljub temu je bilo v zgodovini raziskav Crvenega jezera veliko polemik v sklepih in teorijah o njegovem nastanku, geomorfologiji in hidrologiji. Namen tega dela je podati pregled obstoječih spoznanj o jezeru, kakor tudi predstaviti najnovejše rezultate raziskav, pridobljenih s pomočjo novih tehnologij, ki temeljijo na terestičnega laserskega skeniranja in hidroakustike. Raziskave so potekale septembra 2013. Nova generacija opreme, razvite za napredovanje geoznanstvenih raziskav, je bila uporabljena med delom na terenu. Zbrani podatki so omogočili temeljito analizo, ki je privedlo do novih pomembnih ugotovitev o Crvenem jezeru. Uporabili smo podvodno vozilo na daljinsko upravljanje (ROV), opremljeno $\mathrm{z}$ imaging sonarjem, ki je prineslo prve hidroakustične raziskave jezera. Nekateri rezultati so potrdili že znane in dobro dokumentirane značilnosti jezera, medtem ko so drugi izpodbijali splošno sprejete predpostavke znanstvene skupnosti in širše javnosti. V raziskavi prvič predstavljamo DEM za Crveno jezero, kar je omogočilo oceno o njegovem obsegu. Za najvišji zabeleženi nivo vode na $311 \mathrm{~m}$ nadmorske višine je ocenjena količina shranjene vode $8,24 \times 10^{6} \mathrm{~m}^{3}$.Temperaturni profil jezera je bil posnet med delom na terenu in je ponudil vpogled v možno mešanje vode s kraških kanalov, blizu površini vode. Uporaba TLS in ROV sonarnega sistema je precej izboljšal razumevanje morfologije jezera.

Ključne besede: Lidar, sonar, Crveno jezero (Hrvaška), Dinarski kras.

\footnotetext{
${ }^{1}$ Faculty of Civil Engineering, Architecture and Geodesy, Split University, 21000 Split, Matice hrvatske str. 15, Croatia

E-mail addresses: ivo.andric@gradst.hr (I. Andrić); obonacci@gradst.hr (O. Bonacci)
}

Received/Prejeto: 29.01.2014 


\section{INTRODUCTION}

Red Lake (local name "Crveno jezero") near the town of Imotski (Croatia) represents an impressive surface karst feature in the Dinaric karst with extreme dimensions. The first mention of Red and Blue Lake in literature is over a century old (Cvijić 1893), but since then there have been a few scientific researches. There is a general disagreement in the literature over defining Red and Blue Lake as sinkholes, caves, cenotes, lakes or other karst features. Some of the older researchers argue that both lakes are collapsed dolines. Younger authors argue that Red Lake is a cave, and their conclusions are based on the classification of Union International de Spéléologie (UIS). From a hydrological point of view, Blue Lake Blue Lake has been investigated more, and recent results were published in the paper (Bonacci et al. 2014).

Although the lakes exhibit extreme karst topography, the lack of related scientific work and especially scientific papers published in international journals is evident. The insufficiency in scientific research of Red Lake lies primarily in the difficulties that arise during hydrological and geomorphologic measurements. Because of the inaccessible nature of the local terrain and the extremely steep slopes above the lake shores, measurements are very difficult to obtain, expensive and even dangerous (Bonacci et al. 2014).

The application of Terrestrial Laser Scanning (TLS) for precise modelling of land relief and quantitative and qualitative estimations of spatial and temporal alterations can contribute to better understanding of the pro- cesses shaping the area (Abellán 2006; Oppikofer et al. 2008). This particular remote sensing tool was used to acquire topographic datasets with high accuracy and spatial resolution of Red Lake's geometry model above the water table.

The modern robotic technology, such as ROVs, is used successfully for scientific research, mostly in deepsea exploration (Bachmayer et al. 1998; Yoerger et al. 2007). Industrial work-class ROVs are designed to support a great variety of oceanographic instrumentation, navigate precisely, and provide comprehensive multimodal data-collection ((Bachmayer et al. 1998). This work represents the results of ROV deployment for the purposes of morphological investigation of Red Lake's submerged part. Because of Red lake's great depth over 260 m (Petrik 1960; Garašić 2001), the deployment of ROV was necessary to evaluate lake's geometry at its bottom.

This was the first instance of using emerging technologies in order to obtain the morphometry of this exceptional karst phenomenon. The performed morphological measurements during September 2013, should significantly contribute to the clarification of some unknown attributes of Red Lake. The measures revealed numerous new facts that differ to a great extent from those specified in the existing literature. This work will give an overview of existing facts and summarized conclusions from the publications which deal with the nature of Red Lake.

\section{STUDY AREA}

Red Lake presents one of the world's deepest submerged karst features (Garašić 2001) and some authors believe that Red Lake is one of the most spectacular collapsed dolines in the world (Sauro 2005). It is located in the central part of the bare Dinaric karst region. Located in its immediate vicinity, only approximately $500 \mathrm{~m}$ to the east, is Blue Lake (local name "Modro jezero"). Fig. 1 is a location map showing the area around Red and Blue Lake as well as the hydrological features such as surface stream flows, significant natural karst water phenomenon (Prološko Blato natural retention, Red Lake and Blue Lake) and the locations of three reservoirs.

Fig. 2 shows on the satellite image of both lakes. Red Lake is permanently filled with water, whereas Blue Lake dries up periodically (Bonacci 2006; Bonacci et al. 2014).
The study area is located at the periphery of the Mediterranean climate belt, with a strong influence of continental climate. It is located only $20 \mathrm{~km}$ from the Adriatic Sea, but it is separated from the sea by the Biokovo Mountain chain, which has a maximum altitude of $1762 \mathrm{~m}$ a.s.l. The average annual air temperature in the catchment varies from $12{ }^{\circ} \mathrm{C}$ (northern higher part) to $14{ }^{\circ} \mathrm{C}$ (southern lower part) with a minimum daily temperature in January below $0{ }^{\circ} \mathrm{C}$, and a maximum daily temperature in July and August higher than $35^{\circ} \mathrm{C}$. The annual rainfall ranges from 750 to $2,350 \mathrm{~mm}$ with an average of about $1,500 \mathrm{~mm}$. The maximum rainfall occurs in October and November, and the minimum in July and August. In spite of relatively numerous geological, hydrogeological (especially groundwater tracing) and hydrological investigations 


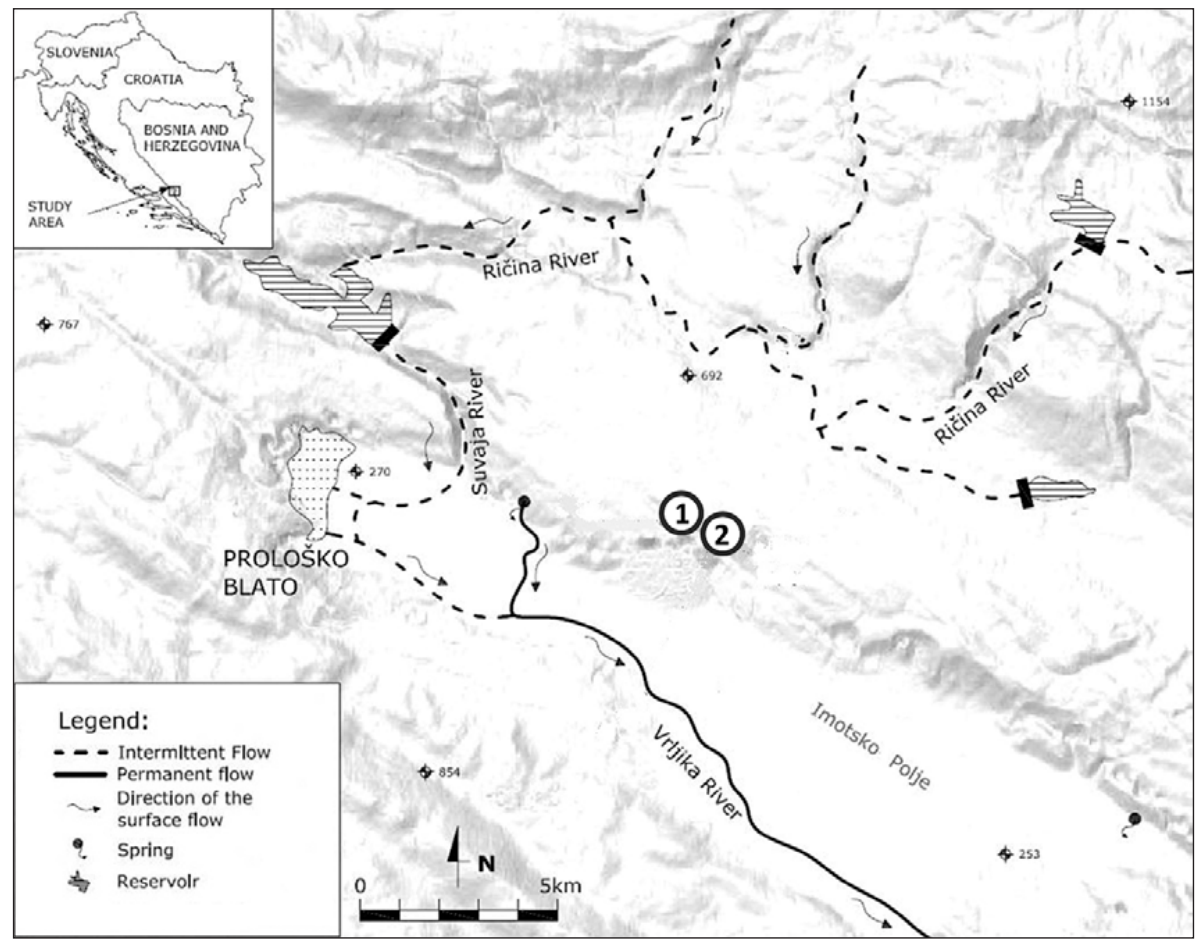

Fig. 1: Location map of the study area with the locations of Red (1) and Blue Lake (2) (Bonacci et al. 2014).

in study area, it has not been possible to define either the catchment boundaries or the directions of groundwater circulation in different hydrological situations during different regional groundwater levels (Bonacci 2006). The reason for this is the extremely complex surface and underground karst morphology.
Fig. 3 represents the geological sketch of the area around Red and Blue Lake, which is a part of the Outer or karstic Dinaric Alps (Herak 1986).

The carbonate rocks of the area are predominantly limestones, and only partly dolomites of Tertiary and Cretaceous formations. The dolomites do not consider-

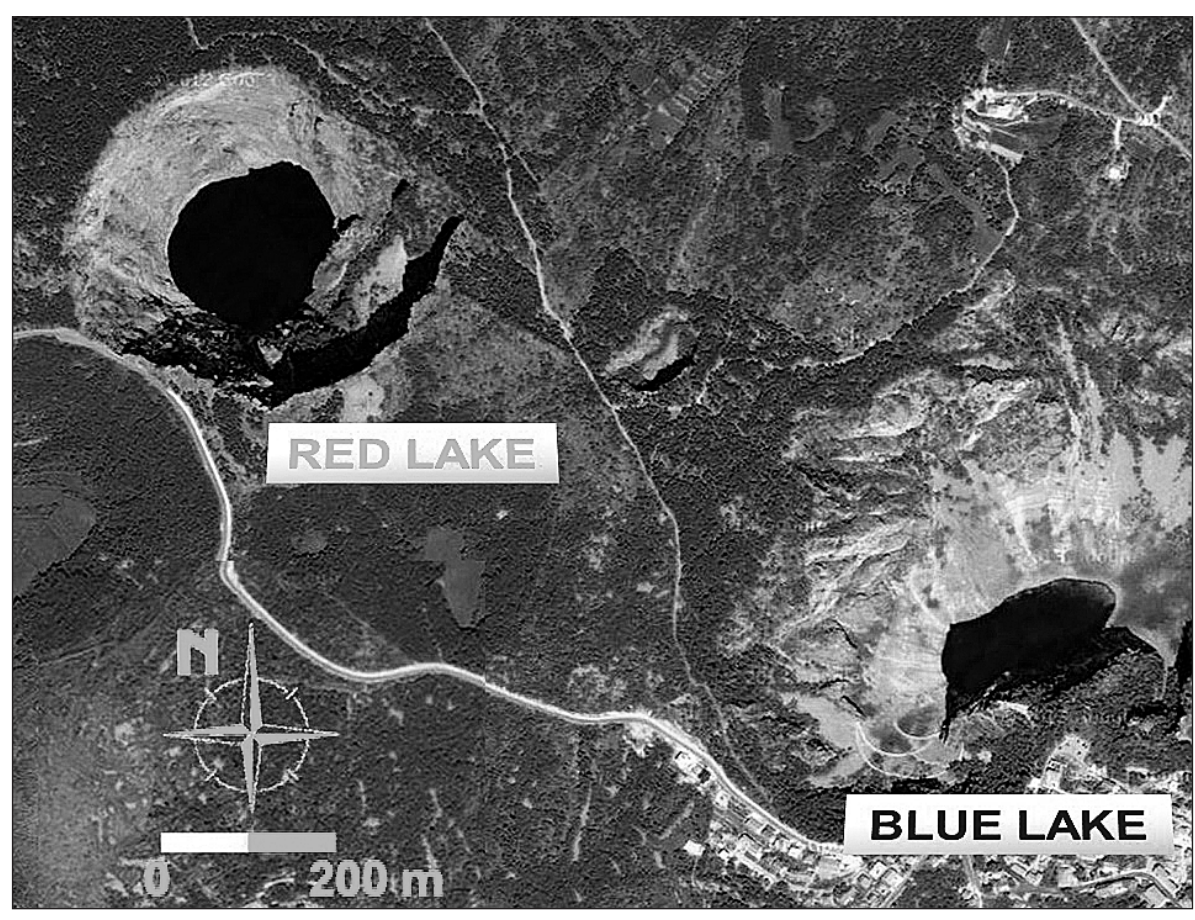

Fig. 2: Satellite photograph of Blue and Red Lakes (Google Maps 2010). 


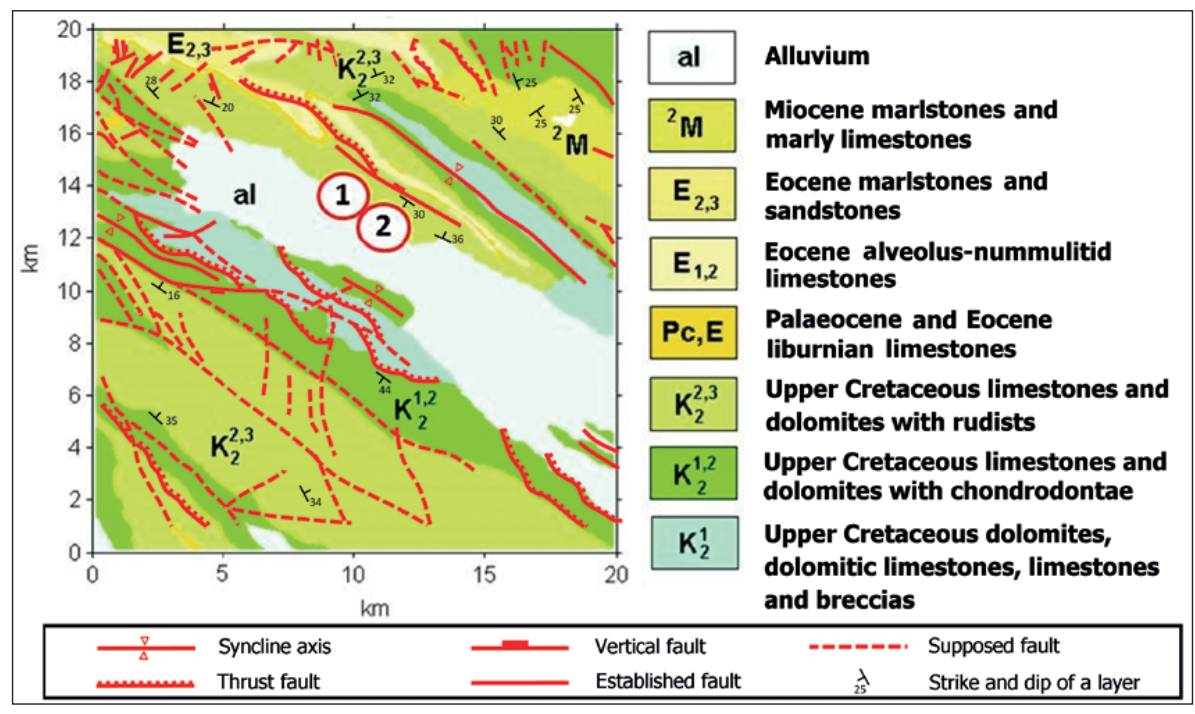

Fig. 3: Geological sketch of the area around Red (1) and Blue (2) Lake (partly after Basic Geological Map of SFRY 1:1,000,000, sheet: Imotski).

ably obstruct groundwater flows. Lower Cretaceous dolomites and thin bedded limestones make underground barriers to groundwater flow. Only after extremely in- tensively precipitations, water table in the limestone, as well as in the broader study area rises up to the surface (Bonacci 2006).

\section{OVERVIEWS OF THE EXISTING LITERATURE}

At the end of the nineteenth and the beginning of the twentieth century Cvijić (1896), Grund (1903), Gavazzi (1903/04) and Daneš (1905) published the first scientific papers about Red and Blue Lake.

Cvijić (1896) established a hypothesis that both depressions were formed by collapsing of the "cave ceiling".

Roglić (1938) suggests that both phenomena are cylindrical shaped dolines, at the same time he excludes the possibility that both lakes functioned as a sinkhole in the past. According to Roglić (1974) a doline is defined as a simple, solitary funnel-shaped and closed karst depression, which is drained at the bottom. It is always wider than deeper and it is formed by corrosion processes and the mechanical activity of surface water and groundwater in areas of karst fissures crossings, resulting in intense water sinking and limestone solution.

Petrik (1960) believes that Red Lake is the youngest doline of all ten significant dolines around the town of Imotski. In the period between April 1955 and June 1956, Petrik was undertaking numerous hydrographic measurements in this region. He measured the highest and the lowest point on Red Lake's rim at $522.9 \mathrm{~m}$ a.s.l. and $425.4 \mathrm{~m}$ a.s.l. respectively. An estimation was given that Red Lake bottom altitude is $4.1 \mathrm{~m}$ a.s.l. At the water level of $254.6 \mathrm{~m}$ a.s.l., Petrik (1960) calculated the surface area of the lake of $32,900 \mathrm{~m}^{2}$.

During the period of measurements, the highest and lowest water levels were recorded at $274.45 \mathrm{~m}$ a.s.l. and $252.78 \mathrm{~m}$ a.s.l. respectively. The amplitude of water level oscillations of Red Lake measured by Petrik (1960) was $21.67 \mathrm{~m}$. He calculated that at the water level of 254 $\mathrm{m}$ a.s.l. water loss from the lake is $89 \mathrm{l} / \mathrm{s}$.

Petrik (1960) also estimated that at water level of $268 \mathrm{~m}$ a.s.l. the volume of water in Red Lake is at least $6 \times 10^{6} \mathrm{~m}^{3}$. Hydrological regime of Red and Blue Lake is considered different and it is assumed that they have no significant relationship with the hydrological regime of Imotski Polje and surrounding area.

Milanović (1981) sees Blue and Red Lake as dolines, by formation the type that usually occurs as a result of the chemical action of water on limestone.

Bahun (1991) analyzes the genesis of Red and Blue Lake in his work. For him, whether Red Lake is a doline or cave is not a problem of terminology problem, rather, it is important from the point of forming of the karst phenomena. Bahun (1991) believes that both lakes are in the carbonate environment and that either lithological or tectonic characteristics did not give a predisposition for the development of these features. His conclusions are substantially different from all previously presented and therefore they 
will be fully quoted: "The results of analysis of the sequence of geological events and of the present hydrogeological relations and the development of the morphology of the wider area of Red and Blue Lake, allow the reconstruction of surroundings in the late Miocene. Northeast of today's Imotski Polje existed a vast lake at elevation of $400-500 \mathrm{~m}$. Back then, there was an elevated region between the lake and the sea. Water from the lake flowed through sinkholes to a lower surface level. Neotectonic caused the differential disturbance of terrain and the area of the former lake got dissected so that some parts were relatively elevated to the present level at $900 \mathrm{~m}$ a.s.l., and some parts were relatively lowered, such as Imotsko Polje, to the current elevation of $260 \mathrm{~m}$ a.s.l. Such movements caused the lake to dry up, sinkholes were left without water so by their exogenous influenced destruction and side collapsing they were turned into a huge sinkhole (Blue Lake) or deep pits (Red Lake). Permanent water and its oscillations in Red Lake as well as the occasional flooding of Blue Lake are the results of the dynamics of underground karst water. It flows through the karst underground of the area from the upper parts in the north and northeast to the erosion base - Neretva River in the east and to the Adriatic Sea in the south.'

Garašić $(2001,2012)$ reports the results of the international cave diving expedition in Red Lake, which took place during September and October 1998. According to him, Red Lake is a water reservoir with a minimum of $16 \times 10^{6} \mathrm{~m}^{3}$ of water. He does not specify whether it is a volume of stored water in the lake or the maximum volume defined by the geometry of the lake. He claims that at the bottom of Red Lake there is a strong flow, in other words an underground river. Garašić $(2001,2012)$ lists the following important results of this expedition: (1) a cave inlet was found east of the lake at the depth of 175 $\mathrm{m}$, measuring $30 \times 30 \mathrm{~m}$; (2) new species of cave fish and shrimp as well as frogs and insects in the lake and its immediate environment have been found and specified; (3) the deepest point on the bottom of the lake at an elevation of $6 \mathrm{~m}$ below sea level has been measured which established a new maximum depth of Red Lake of $528.9 \mathrm{~m}$; (4) at depths below $50 \mathrm{~m}$, a constant water temperature of $7.9^{\circ} \mathrm{C}$ was measured; and (5) the westward movement of groundwater in the bottom of the lake was registered.

Kovačević (1999) suggests that water from Red Lake will leak when the level rises up to a cave on the west side, and that the leak stops when the water level drops. Local residents claimed that the water from these caves overflows in the spring Jažva. Gavazzi (1903/04) documents the existence of this cave and Cvijić (1960) also writes about it. Roglić $(1938,1954)$ and Petrik (1960 did not register the cave's position) during their field research, although its existence was previously documented. The international cave diving expeditions in 1998 recorded more than $300 \mathrm{~m}$ of channels of this cave. On November $29^{\text {th }}, 2011$ the cavers from Imotski Caving Club had the chance to explore the very same dried up cave. At that point, the historically lowest water level of the Red Lake was recorded at $228 \mathrm{~m}$ a.s.l. The cave's influence on the hydrological regime of the lake can partly explain why the maximum water level in Red Lake is lower than the maximum water level in Blue Lake.

Williams (2004) provides the following information about Red Lake: "The deepest known case of collapse doline containing a lake is the Crveno Jezero (Red Lake) in Croatia, which is $528 \mathrm{~m}$ deep from its lowest rim, the bottom of the collapse extending $281 \mathrm{~m}$ below the modern level of the nearby Adriatic Sea. The collapse diameter at the surface is about $350 \mathrm{~m}$ and at lake level is about $200 \mathrm{~m}$. Recent diving has found an active subterranean river that crosses the doline near its floor. The whole feature is thought to have been formed by progressive upwards collapse of cave roof, much of the collapse debris having been transported away by underground river."

Gams (2005) found the reasons for the deep lowering of the bottom of Red Lake in the regional seismic activity that is still present. He notes that seismic station near Imotski registered in the period 1946-1989 the strongest earthquake of 7 degree of MCS. Gams (2005) mentioned that the earthquake that occurred in 1942 reduced the depth of Blue Lake and caused a massive rock fall event in Red Lake. He assumes that the bottom of Red Lake is covered with a thick layer of collapsed rock material.

Bonacci et al. (2013) mention Red and Blue Lake as two exceptional karst phenomena in the complex system of sinking, losing and underground transboundary karst rivers, lakes and aquifers in the central part of the deep and bare Dinaric karst in Croatia and Bosnia and Herzegovina.

\section{METHODS}

In order to obtain an accurate computer model of Red Lake's geometry above the water table the Terrestrial 3D
Laser Scanner (TLS) was used. This instrument is also known as a Ground based LIDAR (Light Detection and 
Ranging system). TLS is one of the most promising remote sensing techniques for slope monitoring because of its capability to accurately acquire dense three-dimensional (3-D) coordinates of the terrain (Bauer et al. 2005; Biasion et al. 2005; Oppikofer et al. 2008). A TLS point cloud data set of the slopes above Red Lake's shores was acquired using a ILRIS 3D Optech ${ }^{\mathrm{TM}}$ laser scanner (Intelligent Laser Ranging and Imaging System). Operation of the TLS is based on stationary distance and its data sampling rate is up to $2,500 \mathrm{pt} / \mathrm{s}$. The laser pulse has a wavelength of $1,500 \mathrm{~nm}$ and a maximum measurable distance of $1,250 \mathrm{~m}$ at $80 \%$ reflectivity. Range measurement can be undertaken using the first or the last pulse of the return signal; the last pulse is the optimal choice to obtain the return signal of the rock face (vegetation filter). Since TLS ILRIS-3-D is constrained by a $40 \times 40^{\circ}$ field-of view, five scan positions were necessary to cover all the slopes at a given distance. The final dataset consisted of five point clouds and over one million measurement points. Some of the measurement points were overlapped due to the repeated scanning from a different angle. The point clouds from each scan position were incorporated into a unique model using the PolyWorks software. The process consisted of unifying all the obtained point clouds from each scan position within 3D space. Geo-referencing was carried out by surveying each scanning position using the total station and GPS receiver. The point cloud data set was filtered with respect to outliers and noise using manual point removal. Generation of a solid surface from a point cloud dataset was carried out through the nearest neighbor gridding interpolation method.

For the purpose of underwater investigations of the lake the remotely operated underwater vehicle, commonly referred to as an ROV, was deployed. The ROV was equipped with a HD camera, precision compass with gyro and sound and navigation and ranging (sonar) systems for hydro acoustics survey. ROVs are used extensively by the offshore drilling industry to support deep water activities (Jones 2009), and are now being increasingly used by the international scientific community for enhanced deep-sea observation, fine scale mapping and sampling (Bachmayer et al. 1998; Yoerger et al. 2007). ROV can accurately measure the depth of the dive and the geometry of the horizontal sections in spherical coordinates. Underwater survey and photographic observations of Red Lake were made with a ROV Seaeye Falcon with maximum operating depth of $300 \mathrm{~m}$. The vehicle control unit and power supply were set on the built floating platform, connected with the ROV through umbilical cable of $450 \mathrm{~m}$ length. Using the equipped digital multi-frequency imaging sonar IMAGENEX 881A, the horizontal sections of the lake were obtained with five $\mathrm{m}$ step. With operating frequency automatically adjusted to $310 \mathrm{kHz}$ and the power of transmitted signal of 23 $\mathrm{dB}$, the range of the sonar goes up to $200 \mathrm{~m}$. The surface that represents the shape of submerged part of Red Lake was generated using the rotary sonar scans and nearest neighbor gridding interpolation of data in 3D space.

The coupling of two geometry models obtained with sonar and lidar technology was made using the PolyWorks software. Due to the gridding of scattered geometry data it was easy to calculate the volume of the lake at any given depth by numerically evaluating triple integral over a given three dimensional rectangular region using MATLAB ${ }^{\circ}$ applications.

All the water temperature measurements of Red Lake were carried out using CTD diver DI 273 SWC with accuracy of $\pm 0.1^{\circ} \mathrm{C}$ and resolution of $0.01{ }^{\circ} \mathrm{C}$.

\section{RESULTS OF THE MEASUREMENTS PERFORMED IN SEPTEMBER 2013}

The most recent hydrological and geomorphologic field research of Red Lake near Imotski resulted with an accurate computer model of Red Lake's geometry.

Fig. 4 presents a computer model of Red Lake geometry, generated using the lidar and sonar data.

It provides a complete picture of the shape of the lake at the very bottom. It shows that at the level of $-4 \mathrm{~m}$ a.s.l., the bottom of the lake has an elliptical shape with dimensions of $20 \times 10 \mathrm{~m}$. Abundance of registered echo return suggests the narrowing of the bottom due to the collapsed material which is confirmed on the recorded images taken with the camera installed on the ROV. The camera also reveals the presence of collapsed material of anthropogenic origin, confirming the rumors that Red Lake has been used for years as an illegal dump for solid waste. Fig. 5 shows two photographs taken at the bottom of the Red Lake.

Because of the risk of damaging the ROV by the sharp metal objects on the bottom, further descent was not possible, although the bottom of the lake goes below the reached depth, expected up to $-6 \mathrm{~m}$ a.s.l. Video recording reveals the presence of suspended particles on the bottom that are steady and only moving due to propulsion activity of the ROV. It proves that earlier assumptions about the active flow through karst conduits on the bottom are not accurate. 


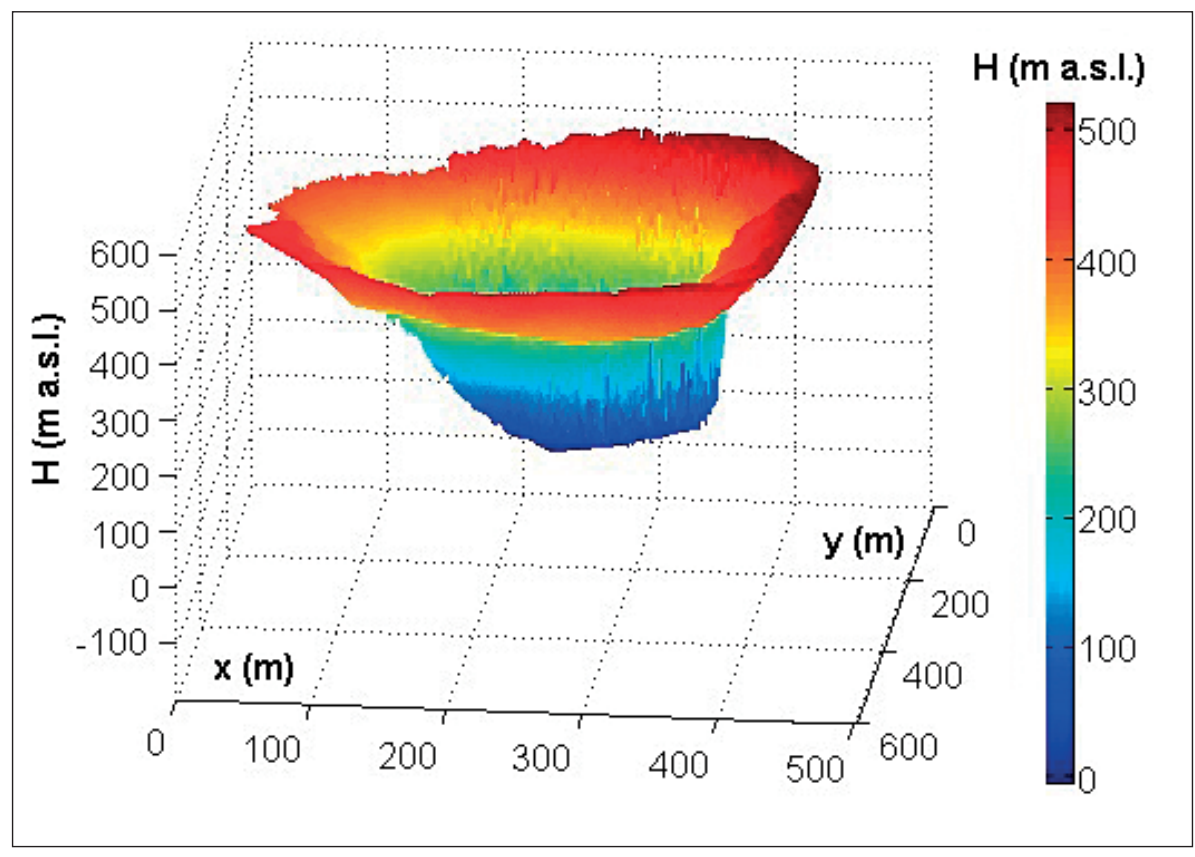

Fig. 4: Mesh/bathymetry model of Red Lake generated using LiDAR and sonar data.

The historical minimum and the maximum water levels of Red Lake were recorded in November 2011 and in April 2013 at $228 \mathrm{~m}$ a.s.l. and $311 \mathrm{~m}$ a.s.l. respectively. This means that the maximum amplitude of water level oscillations in Red Lake is over $83 \mathrm{~m}$. The water level on the day of the survey was recorded at the elevation of $251 \mathrm{~m}$ a.s.l.

Fig. 6 shows four separate sonar images recorded at the following four depths: (1) $5 \mathrm{~m}$ (246 m a.s.l.); (2) $100 \mathrm{~m}$ (151 m a.s.l.); (3) $200 \mathrm{~m}$ (51 m a.s.l.); (4) $255 \mathrm{~m}$ (-4 $\mathrm{m}$ a.s.l.).

The strength of the return echo is shown in a range of colors from red to violet, where red shows the strongest signal, and purple the weakest. The received signal can be affected by various factors such as water temperature, density, suspended particles, distance from the transmitter to the registered object, angle of incidence and the density of the registered solid material. Referring to the examples in Fig. 6, it can be seen that at the elevation of $151 \mathrm{~m}$ a.s.l (diving depth of $100 \mathrm{~m}$ ) echo return was registered over the entire horizontal section with a relatively weak signal. It can be explained with the large operating radius, irregular surface of the lake shore and varying density of the material from which the shore is made. Recorded echo return at elevation of $151 \mathrm{~m}$ a.s.l. registered the lack of feedback signal on the north side of the lake. This can be interpreted in several ways. One explanation may be the location of karst conduit or a vast underwater cave. However, the conclusions should be drawn carefully, because the lack of feedback signal may lie in the refraction and scatter of sound waves due to the geometry and characteristics of the observed material.

Fig. 7 presents the relationship between the elevation of water level $H$ and volume of water $V$ for Red Lake. According to this data, when the water level in the lake reached its historical maximum at the elevation of

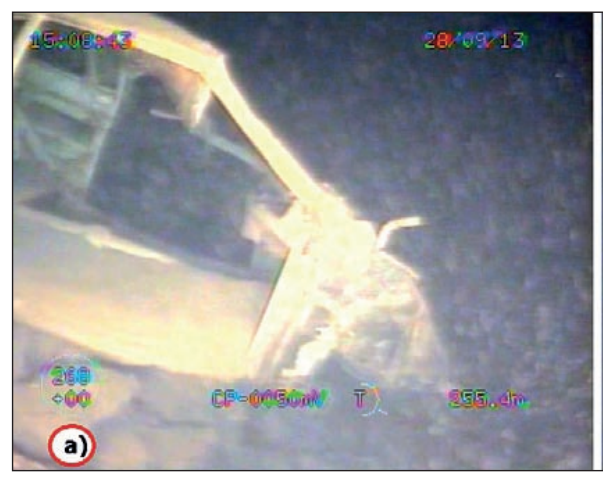

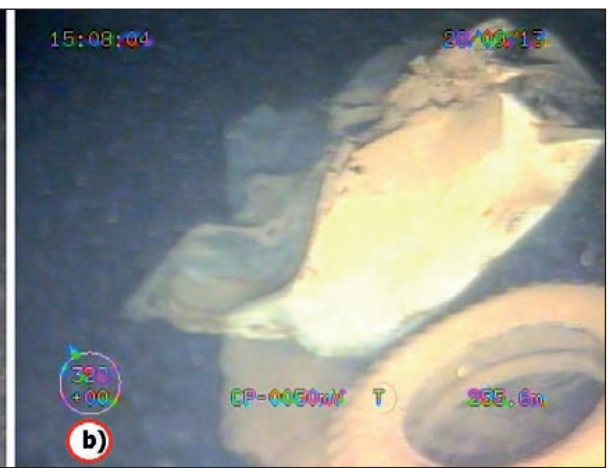

Fig. 5: Underwater photographs taken at depth (elevation) of 255 $m$ (-4 $m$ a.s.l.); heading: a) $268^{\circ}$ and $b) 328^{\circ}$. 


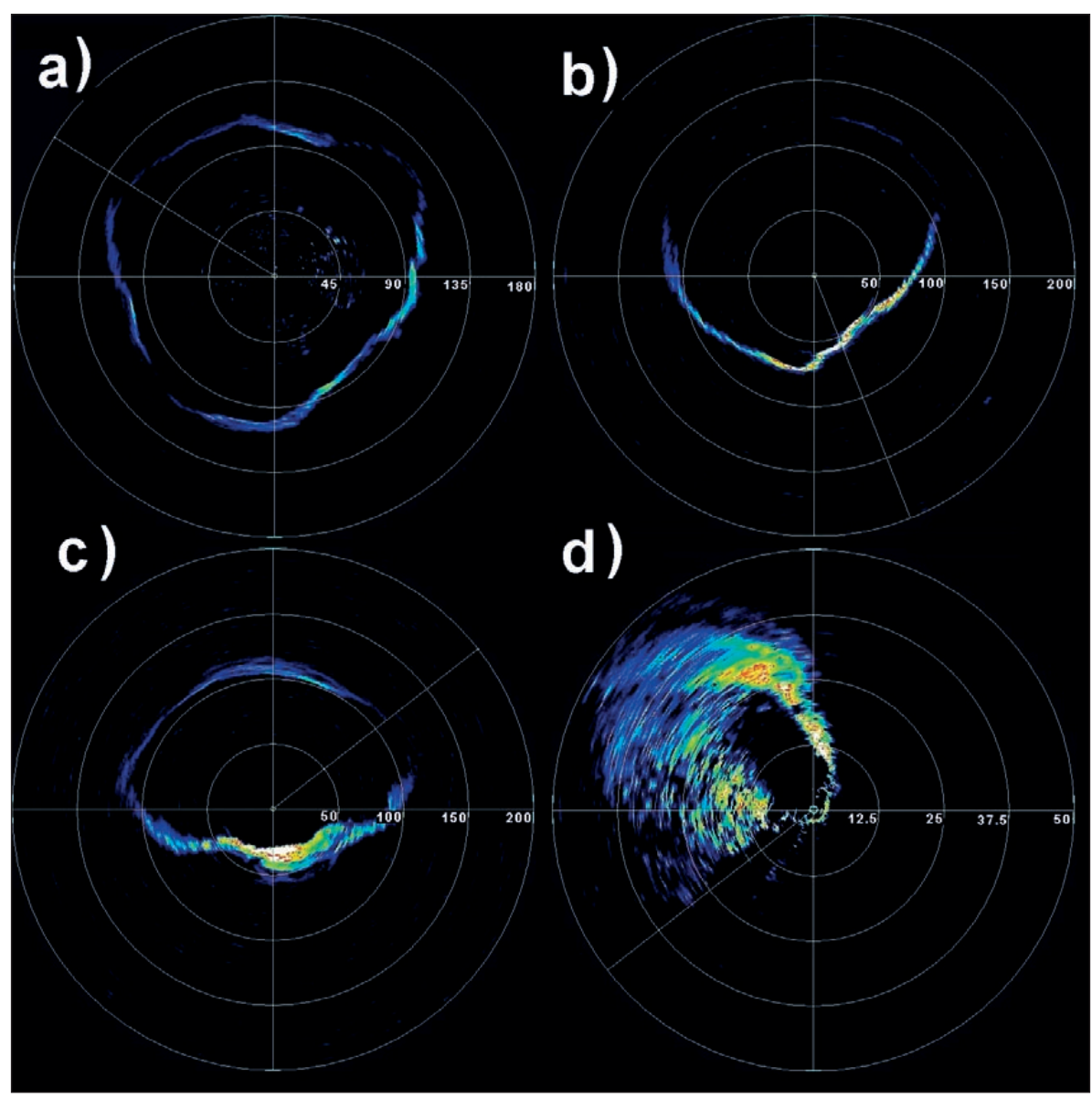

Fig. 6: Sonar recorded horizontal cross sections of Red Lake at depths (elevations) of: $a-5 \mathrm{~m}$ (246 $m$ a.s.l.); $b-100 m$ (151 m a.s.l.); $c-200 m$ (51 $m$ a.s.l.); $d-$ $255 m(-4 m$ a.s.l. $)$

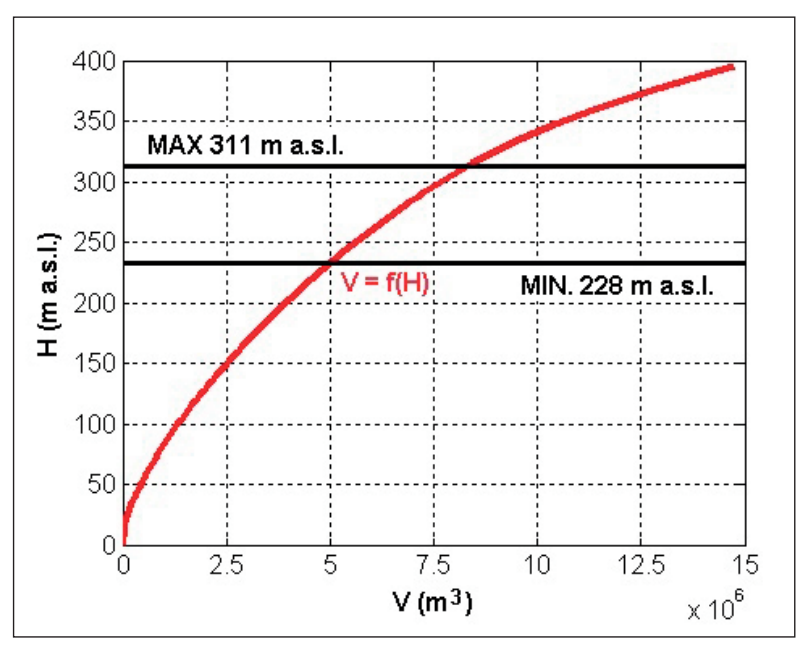

Fig. 7: Relationship between water level, $H$, and the volume of water, $V$.

$311 \mathrm{~m}$ a.s.l., the volume of water stored in it is approximately $8.24 \times 10^{6} \mathrm{~m}^{3}$.

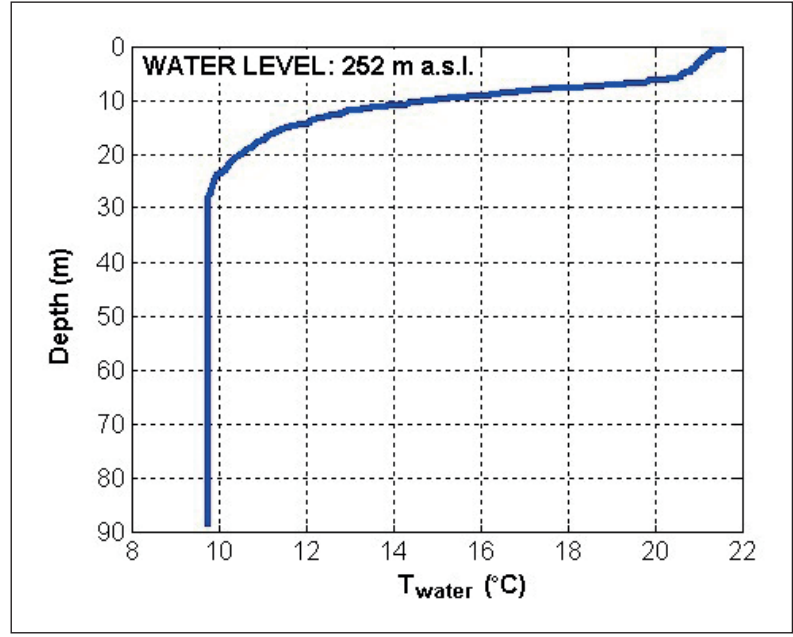

Fig. 9: Water temperature profiles of Red Lake measured 8 Sep. 2013.

Fig. 8 shows two typical cross-sections of Red Lake. By creating the characteristic cross sections of the lake, the position and dimensions of the cave on the west side 


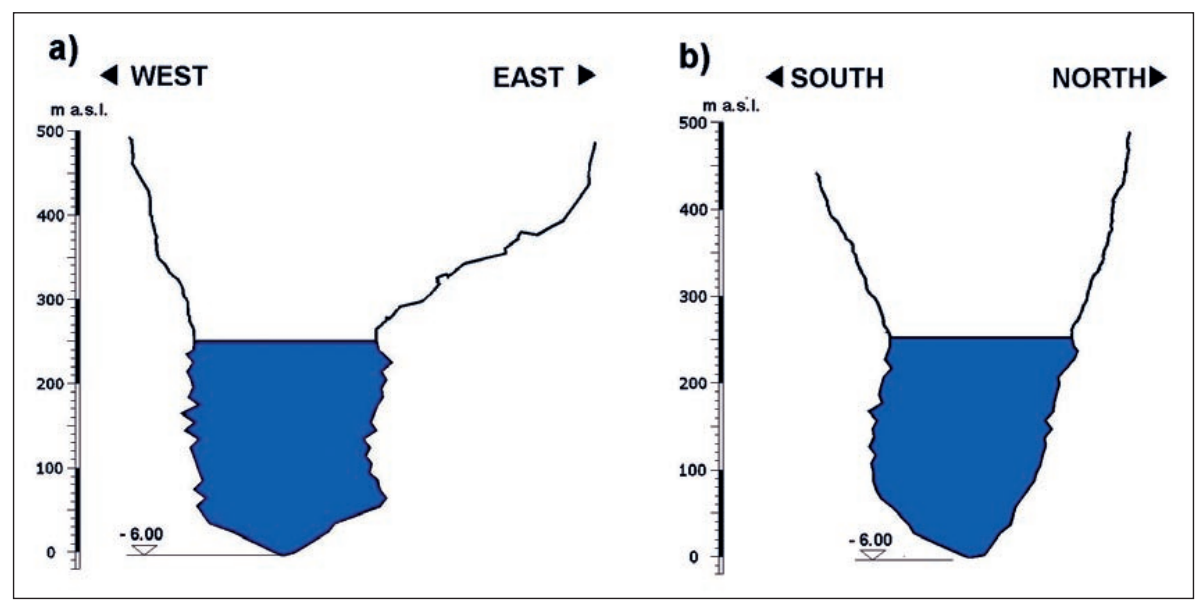

Fig. 8: Two characteristic vertical cross sections of Red Lake.

were ignored as well as the areas without recorded echo return.

The temperature profile at the middle of the lake up to the depth of $90 \mathrm{~m}$ was measured using the CTD Diver. Fig. 9 represents the temperature profile, which shows that the temperature from 30 to $90 \mathrm{~m}$ below the water surface was constant at $10^{\circ} \mathrm{C}$. The water temperature near the surface was recorded at $22^{\circ} \mathrm{C}$. The isotherm at depths below $30 \mathrm{~m}$ also suggests the absence of flow through the great karst conduits thus the low transmission of temperature signal due to the mixing of water.

\section{CONCLUSIONS AND DIRECTIONS FOR FURTHER WORK}

Although the recent research of Red Lake did leave behind some unknowns concerning its geomorphology, more important are the results which indisputably give the answers regarding the lake's basic features such as volume and bathymetry. It is an important turning point in the study of Red Lake because, for the first time, there is a solid base for further hydrological research and modelling in the form of its precisely defined geometry.

The measurements conducted showed the usefulness of TLS in the analysis of the morphology of karst features such as Red Lake. The high-resolution DEM obtained from a point cloud permits spatial analysis with accuracy adjusted to the scale of the phenomena and processes such as lakeshore erosion and material collapse which will be conducted in future research.

This work has also shown that it is possible to use an industrial work-class ROV for morphological study of submerged karst features in deep water. A model of the submerged part of Red Lake was derived from plots of the ROV's track and sonar rotary scans.

The survey integrating TLS and sonar scans provided a complete picture of Red Lake's bathymetry and close landscapes. Data acquired by both sensors was successfully organized into a point cloud representing the mesh/ bathymetry model from which the water level/volume relationship was determined.

During the conducted fieldwork a CTD diver was installed at a depth of $40 \mathrm{~m}$ which continuously records the hourly data of water level, temperature and electrical conductivity. This data will provide insight into the future inflow and outflow of the water from the lake (hydrological and hydrogeological behavior) with regard to the specific geometry defined by the latest measurements. With the water level monitoring which is already in progress, it will be possible for the first time to determine the hydrological budget of the lake.

Further research on Red Lake involves the regular lidar scanning of the lake's shores above the surface of the water to provide an insight into ongoing geological processes of lakeshores on spatial and temporal scale. The research will also consist of periodical temperature and dissolved oxygen records and continuous monitoring of water turbidity. It is of crucial importance to expand the scope of future measurements and to simultaneously measure the hydrological parameters in Red and Blue Lake with the option to monitor other karstic water bodies in the vicinity. An insight into the regional direction of circulation of groundwater would be possible 
with adequate spatial distribution of deep piezometers in the study area.
Further geomorphologic research priorities of Red Lake should concentrate on the exploration of the north side to examine the areas with no signal recordings.

\section{ACKNOWLEDGEMENTS}

This work was created as part of a joint international project of the Croatian Ministry of Science, Education and Sports and the Japanese Cooperation Agency JICA entitled "Risk identification and land use planning for disaster mitigation in landslides and floods in Croatia." Special thanks goes to the company Neptun-SUB Ltd. (Šibenik, Croatia) for the transfer of equipment and pro- fessionals who offered their services free of charge for academic purposes. The authors are especially grateful to ROV pilots Ivan Selak and Dorijano Mohorović as well to the cavers from Caving Club Imotski for their technical support. Without their help, the field research would not be possible. The authors are grateful for the financial support provided by the town of Imotski Tourist Board.

\section{REFERENCES}

Abellán, A., Vilaplana, J.M. \& J. Martínez, 2006: Application of a long-range Terrestrial Laser Scanner to a detailed rockfall study at Vall de Núria (Eastern Pyrenees, Spain).- Eng. Geol., 88, 136-148.

Bachmayer, R., Humphris, S., Fornari, D., Dover, C.V., Howland, J., Bowen, A., Elder, R., Crook, T., Gleason, D., Sellers, W. \& S. Lerner, 1998: Oceanographic research using remotely operated underwater robotic vehicles: exploration of hydrothermal vent sites on the Mid-Atlantic Ridge at $37^{\circ}$ North $32^{\circ}$ West.- Mar. Technol. Soc. J., 32, 37-47.

Bahun, S., 1991: O postanku Crvenog i Modrog jezera kod Imotskog (Genesis of Red and Blue Lakes near Imotski). Geološki Vjesnik, 44, 275-280.

Bauer, A., Paar, G., \& A. Kaltenböck, 2005: Mass movement monitoring using terrestrial laser scanner for rock fall management.- In: von Oosterom, P.; Zlatanova, S.\&. Fendel E. M. (eds) Geo-Information for Disaster Management, Proceedings of the First International Symposium, March 2005, Delft, Springer, 393-406, Berlin.

Biasion, A., Bornaz, L., \& F. Rinaudo, 2005: Laser Scanning Applications on Disaster Management.- In: von Oosterom, P.; Zlatanova, S.\&. Fendel E. M. (eds) Geo- Information for Disaster Management, Proceedings of the First International Symposium, March 2005, Delft, Springer, 19-33, Berlin.

Bonacci, O., 2006: Crveno i Modro jezero kod Imotskog (Red and Blue Lakes near Imotski). Hrvatske Vode, 14(54), 45-54.
Bonacci, O., Andrić, I. \& Y. Yamashiki, 2014: Hydrology of Blue Lake in the Dinaric karst. Hydrological Processes, 28(4), 1890-1898, DOI:10.1002/hyp.9736.

Bonacci, O., Željković, I. \& A. Galić, 2013: Karst rivers' particularity: an example from Dinaric karst (Croatia/Bosnia and Herzegovina). Environmental Earth Sciences, 70(2), 963-974, DOI:10.1007/s12665-012 $-2187-9$.

Cvijić, J., 1893: Das Karstphänomen (Karst phenomena). Versuch einer morphologischen Monographie. Geographischen Abhandlung Wien V(3), pp 218-329, Vienna

Cvijić, J., 1926: Geomorfologija 2 (Geomorpholgy 2).Srpska Akademija Nauka i Umetnosti, pp. 587, Belgrade.

Cvijić, J., 1960: La géographie des terrains calcaires (Geography of carbonate terraines). Naučno Delo, pp. 164, Belgrade.

Daneš, J. V., 1905: Úvodi Dolni Neretvy (The Neretva River Valley). Geomorphologická Studie 8, pp. 108, Prague.

Ford, D. \& P. Williams, 2007: Karst Hydrogeology and Geomorphology.- Wiley, pp. 576, Chichester.

Gams, I., 2005: Tectonics impact on poljes and minor basins (case studies of Dinaric karst).- Acta Carsologica, 34(1), 25-41. 
Garašić, M., 2001: New speleohydrogeological research of Crveno Jezero (Red Lake) near Imotski in Dinaric karst area (Croatia, Europe): International Speleodiving expedition "Crveno Jezero 98".- In: $13^{\text {th }}$ International Congress of Speleology, $15^{\text {th }}-22^{\text {nd }}$. July 2001, Brasilia Speleo Brazil, 168-171, Brasilia.

Garašić, M., 2012: Crveno jezero - the biggest sinkhole in Dinaric Karst (Croatia).- In: EGU General Assembly 2012, $22^{\text {th }}-27^{\text {th }}$ April 2012, Vienna, COPERNICUS, 7132, Vienna.

Gavazzi, A., 1903/04: Die Seen des Karstes (Karst Lakes).Abhandlungen der K. K. Geographischen Gesellschaft 5(2). Lechner, pp. 136, Vienna.

Grund, A., 1903: Die Karsthydrographie. Studien aus Westbosnien (Karst Hydrographic studies in Western Bosnia). Geographischen Abhandlungen 7(3), pp. 200, Leipzig.

Herak, M., 1986: A new concept of geotectonics of the dinarides.- Acta Geologica, 16, 1-17.

Jones, D.O.B., 2009: Using existing industrial remotely operated vehicles for deep-sea science. Zool. Scr. 38, 41-47.

Milanović, P. T., 1981: Karst Hydrogeology.- Water Resources Publications. pp. 434, Littleton.

Oppikofer, T., Jaboyedoff, M., \& H.-R. Keusen 2008: Collapse of the eastern Eiger flank in the Swiss Alps, Nat. Geosci., 1(8), 531- 535.

Optech: ILRIS-3D, 2009: Intelligent Laser Ranging and Imaging System. - [Online] Available from: http:// www.optech.ca/i3dprodline-ilris3d.htm [Accessed $3^{\text {rd }}$ June 2009].
Petrik, M., 1960: Hidrografska mjerenja u okolici Imotskog (Hydrographic measurements near Imotski).Ljetopis JAZU, 64, 266-286.

Roglić, J., 1938: Imotsko Polje - Fizičko-Geografske Osobine. (Physical-Geographic Characteristics of Imotski Polje).- Posebno Izdanje Geografskog Društva 21, pp. 125, Belgrade.

Roglić, J., 1954. Polja zapadne Bosne i Hercegovine (Karst poljas of Western Bosnia and Herzegovina).In: III Kongres geografa Jugoslavije, 1953, Sarajevo, Geografsko društvo NR BiH, Sarajevo.

Roglić, J., 1974: Prilog Hrvatskoj Krškoj Terminologiji (Contribution to Croatian Karst Terminology).Carsus Iugoslaviae 9/1, 72.

Roglić, J., 1974: Odnos između površja i podzemlja Dinarskog krša (Relationship between surface and underground of Dinaric karst).- Acta Carsologica, 6, 11-19.

Sauro, U., 2005: Closed depressions.- In: Culver, D. C. \& White, W. B. (eds.) Encyclopedia of caves. Elsevier, pp. 108-122, Amsterdam.

Williams, P., 2004: Dolines.- In: Gunn, J. (ed.) Encyclopedia of caves and karst science. Fitzroy Dearborn, pp. 304-310, New York, London.

Yoerger, D.R., Bradley, A.M., Jakuba, M., German, C.R., Shank, T. \& M. Tivey, 2007: Autonomous and remotely operated vehicle technology for hydrothermal vent discovery, exploration, and sampling.Oceanography, 20, 152-161. 